\title{
Conceptions of tourism lifestyle entrepreneurship: transition economy context
}

This article was published in the Journal Tourism Planning and Development (2011) vol. 8, issue 2, pp.157-169 DOI: URL: http://dx.doi.org/10.1080/21568316.2011.573915

\section{Authors' Details:}

Dr Vlatka Skokic

School of Management

University of Surrey

Guildford

Email: v.skokic@surrey.ac.uk

Phone: 0044 (0) 7809766384

Professor Alison Morrison

School of Management

University of Surrey

Guildford

Email: a.morrison@ surrey.ac.uk 


\title{
Conceptions of tourism lifestyle entrepreneurship: transition economy context
}

\begin{abstract}
Lifestyle, non-economic motives have been recognised as a significant motivational factor for tourism and hospitality entrepreneurs. However, knowledge on the subject is mainly drawn from the perspective of western developed economies, with a paucity of studies focusing on transition and developing countries. The purpose of the paper is to investigate tourism entrepreneurship within the former socialist countries, particularly focusing on Croatia. The study is based on in-depth interviews with tourism entrepreneurs in the Splitsko-dalmatinska county. The paper argues that understanding of entrepreneurship can be enhanced if theories are contextualised within a specific setting and industry sector and thus applies Morrison's (2006) 'drilling down' model in investigating tourism entrepreneurship. The results reveal a non-existence of lifestyle entrepreneurs and a conceptual model is developed to encapsulate the complex range of factors which underpin the different behaviour of the analysed entrepreneurs. Implications for entrepreneurship theory and further research are discussed.
\end{abstract}

Keywords: tourism entrepreneurship, lifestyle entrepreneurs, transition economies, qualitative methodology

\section{Introduction}

Tourism entrepreneurship has remained a largely neglected area of research (Ioannides and Petersen, 2003; Li, 2008; Thomas, 2004). In their recent contribution, Ateljevic and Page $(2009$, p.1) argued that 'the links between tourism and entrepreneurship, with a few exceptions, remain divergent themes that are not addressed in any way which draws upon the inherent synergies between the two areas.' The subject of entrepreneurship has been studied from a multitude of disciplines (Hébert and Link, 1988). However, contributions to understanding and 
knowledge of what constitutes entrepreneurship and entrepreneurs started with an interest in the phenomenon by economists. This perspective has failed to explain the motivation of numerous small businesses in tourism which defy models of economic rationality, that of lifestyle entrepreneurs.

Since Williams et al., (1989) initially observed the lifestyle concept, many subsequent studies have confirmed the prioritization of a certain, consciously selected lifestyle by a significant number of tourism and hospitality entrepreneurs, over a focus on business growth and profit maximization. Twenty years after their study small tourism and hospitality firms are often generically described as lifestyle enterprises (for example, Ateljevic and Doorne, 2000; Getz and Petersen, 2005; Ioannides and Petersen, 2003; Lashley and Rowson, 2010; Morrison et al., 2001; Mottiar, 2007; Shaw and Williams, 2004). These studies revealed numerous characteristics associated with lifestyle entrepreneurs including: non existence of management strategies and limited return-on-investment based strategies (Morrison, et al., 2001); lack of involvement in formal organisations (Mottiar, 2007); low education and training, and the lack of skills (Lashley and Rowson, 2010); limited innovative strategies (Ioannides and Petersen, 2003); and entry is often related with a lifestyle choice, such as to move to certain place or 'to be my own boss' (Getz and Petersen, 2005). Nevertheless, the majority of those studies were conducted within the context of western developed economies, with a paucity of studies focusing on transition and developing countries (Morrison, et al., 2009). Therefore, different world views which exist relative to the same phenomena are difficult to recognise and conventional wisdom is questioned.

This paper argues that the lifestyle concept represents an elusive concept which needs to be conceptualised in 'a manner which recognises the influence of sub-sector, national cultures, 
location, and domestic circumstances' (Thomas, 2004, p.10). In the study reported in this paper this was achieved by researching small hotel entrepreneurs in Splitsko-dalmatinska county, Croatia, as a former socialist and transition economy. It places the tourism entrepreneurs into a specific context and argues that understanding of entrepreneurship can be enhanced if theories are contextualised within a particular culture and industry sector.

Morrison (2006) proposed a 'drilling down' model for researching entrepreneurship. This model moves from uni-dimensional understanding of entrepreneurship and proposes that the phenomenon should be investigated by encompassing the impact of culture, industry setting and organisational context, supporting the aforementioned argument central to this paper. These levels may act as 'filters that either intensify or dilute the entrepreneurial process resulting in consequential entrepreneurial socio-economic outcomes' (ibid.,192). Therefore, the paper begins with a review of literature pertaining to tourism entrepreneurship and outlines the social context and the nature of the industry where entrepreneurs operate. It continues with a brief description of the analysed setting and study method. It is important to emphasise that the paper draws on the literature developed from the Western economies, as the sources from the perspective of transition economies are scarce and there exist a significant gap in knowledge (Skokic, 2010). The most pertinent findings are presented and discussed in the context of previous studies of tourism entrepreneurship. The paper concludes with a consideration of the study's implication for the broader theoretical framework and contribution to knowledge.

\section{Theorising lifestyle entrepreneurship}

In order to determine lifestyle orientation, the majority of tourism entrepreneurship studies explored owner-managers' motivation to start-up business and their intention to grow (Getz 
and Petersen, 2005; Hall and Rusher, 2004; Komppula, 2004). Besides these, scholars linked other issues with a lifestyle orientation, such as the role of innovation (Ioannides and Petersen, 2003), or inter-firm relations (Mottiar, 2007). This paper considers those as outcomes of entrepreneurial orientation and, as such, they will not be analysed. It aims to understand the lifestyle concept in a broader perspective. Morrison's (2006) framework, besides providing explanatory power for the concept, contributes to the understanding of this study's findings and enables the isolation of the factors which led to the reported behaviour of Croatian entrepreneurs.

\section{Culture}

The overall culture and conditions for entrepreneurship can be defined as informal institutions which include the norms, beliefs, values, and similar conventions that form socio-cultural relations within a society (North, 1990). Entrepreneurial ventures present novelty, are unique (Aldrich and Fiol, 1994) and therefore can confront 'problems associated with lack of legitimacy' (Low and Abrahamson, 1997, p.436) or external validation (Stone and Brush, 1996). Western economies are in general defined as supportive of entrepreneurship as they provide both adequate formal institutions and strong entrepreneurial culture. Formal institutions refer to the rules, regulations, laws and supporting apparatuses that establish order in economic, legal and political framework (North, 1990). Entrepreneurial culture can be described as a positive social attitude towards personal enterprise (Timmons, 1994). In societies where this is strong, entrepreneurs are variously seen as heroes (Ogbor, 2000), warriors (Hornaday, 1990), and agents of economic change (Schumpeter, 1934). However, centrally planned economies, with their ideology and overall institutional framework limited the level of entrepreneurial alertness (Ireland et al., 2008). This had significant implications for repressing entrepreneurial culture, as is further explained within the example of Croatia. 


\section{Industry setting}

In the western developed world the tourism industry attracts entrepreneurs due to low legal and professional barriers to entry (Lockyer and Morrison, 1999; Morrison, 1998). An ease of entry also enabled them to hold various types of occupations, but portfolio or serial entrepreneurs could rarely be found (Buick et al., 2000). These characteristics produce industry sector specific lifestyle entrepreneurial behaviour. Morrison (2006) argued that entrepreneurs will assess the feasibility and desirability of the industry setting as a site for both social and economic investment. However, former socialist countries had significant entry barriers within all sectors and tourism was not an exemption. The barriers range from financial (Ageev et al., 1995), institutional (Manolova et al., 2008), and fiscal (Kolodko, 2000), which significantly lowered the level of entrepreneurship (Ayyagari et al., 2007; Chilosi, 2001).

\section{Organisational context}

Morrison (2006) proposed that organisational context should be analysed relative to the organisational structure, organisational behaviour, and resources. In terms of organisational structure, the founding-entrepreneur presents the heart of the structure (ibid.). In tourism entrepreneurship literature the issue of owner-managers start-up motives has been widely debated. Studies have identified a range of entrepreneurial cultures, which can range from a preoccupation with economic motives through to a vast range of non-economic factors. Those non-economic factors, such as: to move away from hectic urban life (Alexander and McKenna, 1999); freedom of being own boss (Lashley and Rowson, 2010); or to be able to live in a specific area (Shaw and Williams, 1987) seem to appeal to the heart of small business owners. Consequently, a vast number of scholars argued that they can be termed as lifestyle entrepreneurs. Analysing models of entrepreneurship, Shaw and Williams (1998) argued that this group operates as non-entrepreneurs. They further distinguished a second group called 
constrained entrepreneurs mostly young people with a greater level of economic motives but constrained by lack of business skills and capital.

A few studies also revealed the mutual existence of lifestyle and business goals. Exploring small accommodation providers in Scotland, Morrison and Teixeira (2004) found that business entry motivations reflected a mix of personal and business circumstances, but are dominated by those associated with family. This was also confirmed by Hall and Rusher (2004) analysing Bed and Breakfast operators in New Zealand, and Shaw and Williams (2004) in a study of 'surf-entrepreneurs' in Cornwall, England. Nevertheless, only two studies have been identified which reported the non existence of the lifestyle entrepreneur within the sector. Research carried out by Glancey and Pettigrew (1997) and Buick et al., (2000, p.129) within the small hotel sector in Scotland found that respondents 'are definitely interested in the survival and growth of the business.' These findings indicate that sectoral characteristics might play an important role in explaining the behaviour and development of small business and it is of crucial importance for researchers to recognize them.

In terms of organisational forms, the majority of the small businesses take the form of partnership among spouses and family members, where in many cases it is a husband and wife team (Ateljevic, 2009; Getz and Petersen, 2005). This is further emphasized within those businesses where the owners live in the premises (Lynch, 1998). Another distinctive feature of the organisational structure is the business 'smallness'. In small firms, relationship between owners/founders and managers, usually combined in one or two individuals is typically closer than in larger firms, and growth as one of the management strategies does not have to be an objective (Dobbs and Hamilton, 2007; Shepherd and Wiklund, 2005). Some entrepreneurs choose not to expand the firms because that would be in contrast with their desire to retain 
control of decision making (Glancey, 1998). For instance, in Morrison and Teixeira's (2004) study the owners perceived that growth will result in loosing distinctive attributes associated with smallness, while from managerial perception it is deemed undesirable because of financial and human resource poverty.

Owner-managers' strategic awareness is strongly influenced by personal competencies, linked to the level of education, entry motives, business experience and the type and complexity of the business. From analysis of literature, it is obvious that for a vast majority of ownermanagers, 'lifestyle is a strategic business objective' (Hall and Rusher, 2004, p.94), thus, it permeates organisational behaviour. Studies revealed that: small firms do not engage with different marketing activities (Ateljevic, 2009; Page et al., 1999); do not exploit the benefits of IT (Buhalis and Murphy, 2009); are not engaged with quality strategies (Church and Lincoln, 1998; Taylor, 2008); and have low level of formal business planning (Ateljevic, 2007).

In terms of organisational resources, small firms in general do not employ labour to a great extent and rely on family (Scase, 2003). This was also evident within the sector, where Shaw and Williams (1987) found analysing the Cornish tourism and hospitality industry that $62 \%$ of firms were managed by an owner-purchaser. Similar results are evident from most of the studies analyzing small tourism and hospitality businesses. Scase and Goffee (1989) further argued that the majority of the enterprises in the personal service sector, such as small hotels, are only profitable because the costs are subsidised by the unpaid services of family members. The lack of skilled employees also negatively affects business performance (Ateljevic, 2007; Morrison and Teixeira, 2004), and even growth because of the owner-managers reluctance to employ a full-time work force outside the family (Komppula, 2004). Szivas (2001) additionally proposed that the general portrait of tourism entrepreneurs which she termed as 'amateurs', 
combined with the lack of skilled workers, can also have a negative impact on the quality of the service provided.

The most important source of start-up funding is personal funds (self-finance) and money from family and friends (Ateljevic, 2009; Glancey and Pettigrew, 1997; Lashley and Rowson, 2010). This might be due to limited supplies in external funding and an inability of the owners to use external financial sources. On the other hand, their lifestyle orientation can also be the cause, where the external borrowing might present a threat to their personal autonomy (Curran and Blackburn, 1994; Stanworth and Curran, 1976).

Literature reviewed indicates that the lifestyle concept is a complex issue, may vary within sectors and can exist collaboratively with economic motives. However, what is known about the concept originates from Western discourse. Thus, it can be argued that the lifestyle phenomena needs new movements in research, which focus 'on understanding the interplay of culture, context and social process that provide the architecture for such largely subjective initiatives' (Morrison et al., 2009, p.10).

\section{Research context}

The development of entrepreneurship and the small business sector in Croatia must be considered in the context of its historical framework (Figure 1), which strongly influenced entrepreneurial activity and the level of tourism development.

Figure 1 Historical framework 


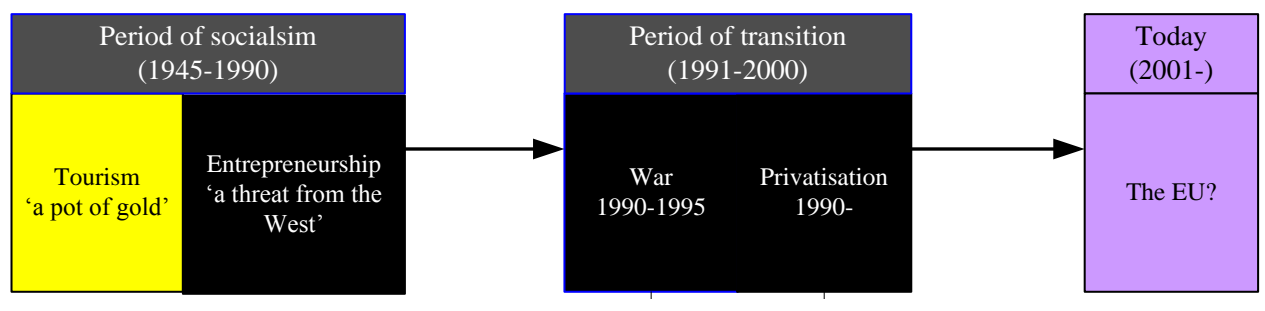

From Figure 1, it can be seen that entrepreneurial activity was significantly constrained by a socialist regime and transition period. The main barrier was the overall ideology which aimed to create a system above capitalism and where private property was associated with exploitation and profiteering, 'leaving a lasting stigma on individuals pursuing entrepreneurial opportunities' (Manolova et al., 2008, p.206). Entrepreneurs were portrayed as individuals incapable of securing a public sector job. Entrepreneurship was viewed as a phenomenon coming from capitalist ideology aiming to achieve material gains through the exploitation of others (Kovac, 1990). Tourism was one of the rare industries were private initiative was developing, especially among the accommodation sector. In 1974 the government enabled the establishment of private enterprises in agriculture and hospitality. By constitution, the government restricted the size of the business in terms of employees. Five employees could be employed as a maximum, but only in exceptional circumstances (Kobasic, 1987).

After 1965, tourism in ex-Yugoslavia was regarded as a 'pot of gold' (Allcock, 1986). During this period, the government invested considerable money into the accommodation sector. Until 1975 almost $70 \%$ of all accommodation capacities was built which Croatia disposed of in 1990 (Kobasic, 1987). But the rise in quantity of accommodation facilities did not reflect an adequate increase in quality. They were built as 'this was useful to superior objectives...and the tourism sector was abandoned to unsystematic development which consequence still can be felt' (Pirjevec and Kesar, 2002, p. 53). However, the entrepreneurial spirit was growing despite 
all restrictions. Entrepreneurial movement was especially prevalent within the accommodation sector where a vast number of people started to rent summer houses operating illegally. Although it can be argued that this behaviour is not entrepreneurial nor productive (Baumol, 1990), other forms of entrepreneurship could not be performed as the government restricted the major conditions for entrepreneurship.

The transition period was marked by an inappropriate privatisation policy which enabled frauds by privileged individuals called entrepreneurs, that has created an image for the entrepreneurs as corrupt criminals. This negative image was significantly reflected in the hospitality sector and manufacturing industry where the government enabled these entrepreneurs to buy enterprises far below market price with an obligation to invest money and increase employment. The situation in practice was the opposite, where people who bought those enterprises would strip out equipment, fire workers and abandoned it. Consequently, the image portrayed of the entrepreneur was even worse than in times of socialism. Namely, people perceived entrepreneurs as privileged criminals, tycoons, connected with corruption, whose wealth has been obtained through devious means.

Currently, entrepreneurship is becoming a philosophy of progress, and the entrepreneurs who create new values and new jobs are seen as capable individuals who 'build a welfare state and economy' (GEM, 2002). Thus, the entrepreneurial climate in Croatia is changing, becoming more of a stimulant for entrepreneurial activity. However, Croatia is, according to GEM (2006), still experiencing difficulties in fostering entrepreneurial activity. This is obvious when comparing the GEM data. It confirms that the number of entrepreneurs who have become entrepreneurs due to a business opportunity is much lower that the number of those who have become entrepreneurs out of necessity. In global comparison, rates of necessity 
entrepreneurship in developing countries can be five times higher than observed in developed ones (Reynolds et al., 2003). Baker et al., (2005, p.497) stressed that these differences 'point to the importance of national context in shaping the opportunity set and consequently the opportunity cost evaluations of potential entrepreneurs'. In Croatia's case this might be due to the national economic-political system which generated many economic, social, psychological and general barriers to entrepreneurial ventures, such as: the collective decision-making process which hindered individual initiatives; the lack of private savings and limited accessibility to credit money; mistrust towards people not belonging to the ruling party; and corruption and profiteering as substitutes for entrepreneurship (Bartlett and Bateman, 1997; Glas, 1998).

\section{Research Method}

A major research methodological challenge was to disclose complex relationships which exist between entrepreneurs and their external and internal environment and enable explicit incorporation of the analysed social setting into the research design. Also, this study argues that entrepreneurship represents a dynamic and socially constructed phenomenon which can not be reduced to its simplest elements, and causal relationships with fundamental laws applicable to different settings. This demanded an interpretivist stance and qualitative methodology. It aims to interpret and understand social life, to discover people's meanings which are attributed to different situations and actions, and also it acknowledge an observer as a part of the observed process (Burrell and Morgan, 1985).

The research was conducted in the Splitsko-dalmatinska county of Croatia and this constitutes the first phase of the sampling process. This region is recognised as the best representative for the research due to the following reasons. Firstly, it has a long established tourist tradition, 
which dates to the period around 1868 (Vukonic, 2005). Secondly, in recent years entrepreneurial activity within the tourism and hospitality industry has grown rapidly in this area which enables the researcher to find 'the best representative' population for the research objectives. However, perhaps the most significant reason is that the researcher originates from the area giving potential for an 'insider' perspective which helped her to unpack complexities when analysing data of a social, political and economical nature which underlay entrepreneurship and tourism development. This perspective also proved fruitful in the work of Ateljevic and Doorne (2003) who investigated tourism entrepreneurship in the context of socio-cultural issues in the post-Communist period in the village of Murter, Croatia. The unit of analysis was determined to be individual entrepreneurs, small hotel entrepreneurs operating within the county, which determined the second stage in the sampling process. Different criteria are used to define what constitutes a small hotel, such as number of bedrooms, bedspaces or number of employees (Buick et al., 2000; Morrison et al., 1996; Peacock, 1993). Croatian sources do not identify a size criterion and the researcher decided that for the purposes of sampling issues a small hotel will be the one which does not have more than 40 rooms. This approach was selected due to a reason of more technical nature. The Croatian Ministry of Tourism started to monitor the number and spatial distribution of small hotels more precisely due to the established credit line 'Incentive for Success', where a small hotel is defined as one having up to 40 rooms. This helped the researcher in creating the database of small hotels necessary for this research. From the National Hotel Categorisation data the researchers identified 64 small hotels out of 114 in the analysed county.

Non-probability, purposive sampling was selected, where sampling is on the basis of interviewing people who are relevant to the research questions. Patton (2002, p.46) argued that the main strength and logic is in-depth understanding of 'information-rich cases'. Originating from the area and being aware of the mentality of the population the researcher knew that 
respondents would appreciate much more phone over email contact, otherwise they were unlikely to respond. Hence, the researcher used personal networks and sources on the internet to obtain mobile phone numbers from the potential interviewees, which generated a database necessary to conduct the research. When the numbers were obtained a letter was sent to explain the purpose of the study and the method employed. Approximately five days after sending the letters the researcher would phone the small hotel owner to ascertain their willingness to participate in a face-to-face interview. Surprisingly, no one refused. Only three of the contacted owners did not arrange for an interview because they were facing a difficult family situation.

Insider perspective is often criticised as being overly subjective. It is argued that subjectivist orientation can undermine researchers' credibility with an audience and also masks their ability to judge when analysing data (Hollinshead, 2004). To overcome this problem, qualitative researchers propose an 'empathic neutrality' (Patton, 2002). This position takes a middle position between objectivity and subjectivity, recognising that 'research cannot be value free but...researchers should make their assumptions transparent' (Snape and Spencer, 2003, p.13). However, this position does not provide techniques to evaluate and judge emerging data. One used in this study was the key informants technique throughout the overall research process. The key informants included two university professors from Croatia and policy representatives involving: the President of the Association of Small Hotels; the President and the Vicepresident of Croatian Bank for Reconstruction and Development; Vice-President for the Ministry of Tourism; and the officials from the Ministry of Economy, Labour and Entrepreneurship. This technique helped the researchers to compare and contrast the entrepreneurs' accounts, to direct the research, give it context and provide rich background knowledge. 
The researcher interviewed 33 small hotel entrepreneurs in urban, island and inland areas, thus comprehending the whole research setting (Denzin and Lincoln, 2000). The overall number of conducted interviews was theoretically dependent (Strauss and Corbin, 1998). Among the researched population there were five hotels which had paid managers and in those cases both managers and owners were interviewed. The main data collection methods were semistructured interviews. Most of them were conducted in the hotels. On average the interviews lasted from one hour to three and a half hours. The interviews were tape recorded. In order to ensure transcription quality and accuracy of the transcribed text, a decision was taken that the interview transcription would be conducted in the Croatian language and Dalmatian dialect. Being completely familiar with the text, meanings and interpretations within it, the researcher was able to conduct data analysis. Framework analysis (Ritchie and Spencer, 1994) is adopted as a main analytical method. Nine meta codes emerged after rigorous analysis of the transcripts. In relation to this study, to determine the existence or not of the lifestyle orientation, the meta code 'life history and business orientation' will be analysed. In order to develop a more holistic understanding, these findings will be viewed against the backdrop of the presented 'filters' (Morrison, 2006) which serve as explanatory mechanisms of the entrepreneurial behaviour. In this study, they are represented through a meta code 'environment for entrepreneurship'.

\section{Findings}

The main aim of the study, to reveal entrepreneurial orientation in the context of broader cultural and organisational context will be assessed in the following way. Firstly, a brief outline will be given on the entrepreneurs' socio-economic characteristics, continuing with the examination of their entry motives and consequent future goals. These findings will then be placed in a broader picture of cultural and organisational setting. 
The majority of interviewed entrepreneurs were between the ages of forty and forty-nine and were male, accounting for twenty-seven out of thirty-three. The majority of them had university education, but only a minority holds a tourism and hospitality university-level degree (six out of twenty-three). The wide diversity of university background is evident, with degrees ranging from economics, law, chemistry and art. Twenty-nine businesses were registered as a sole proprietorship and four as a joint partnership. In terms of gender, only two women are sole proprietors and run the business independently. The length of time entrepreneurs had owned their businesses varied from forty years (one owner) to just one year (one owner). The majority own their businesses from two to four and from five to nine years. Most of the hotels had between 10-19 (thirteen) and 20-29 (twelve) rooms.

The findings revealed that almost all entrepreneurs (thirty-one) had previous experience of owning and managing small business. Only three had experience of running a small accommodation business in the form of private apartments. As these entrepreneurs owned those businesses during the period of socialism it is not surprising that they opted for apartments, as ownership of hotel business was not permitted for individuals. The remaining entrepreneurs had run small businesses in a wide range of different sectors, including trade, financial, electronics, restoration, bakery and physical therapy sectors. Furthermore, only three entrepreneurs from the sample do not own other businesses besides the hotel. Thus, it is possible to categorise them as serial and portfolio entrepreneurs. All entrepreneurs viewed such experience of owning and managing small businesses in other sectors as beneficial in terms of providing a basic skills and competencies. However, a decision to start a small hotel business was not connected to the previous experience of running a small tourism and hospitality or any other business. Twenty-nine entrepreneurs stated that their decision was purely based on the 
spotted opportunity. Those entrepreneurs who had experience of running small tourism businesses also stated that this has not influenced their decision to open a small hotel, but they saw an opportunity 'and the idea came naturally'. Identified entry motives can be summarised under following categories: lack of accommodation capacities in the county; popularity of small hotels internationally; strength and the importance of the tourism sector for Croatian economy; and an opportunity to expand existing business portfolio.

In contrast, only one entrepreneur revealed a purely lifestyle entry motives. That was dissatisfaction with a job in a state owned company combined with a desire to move to an island and leave something to their children. Another entrepreneur had combined lifestyle and profit oriented motives where the remaining two were 'pushed by lifestyle circumstances' which reflect some attributes of the socialism and transition period.

Closely connected with the entrepreneurs' profit orientation are their future goals expressed in terms of business growth. All but five entrepreneurs desired business growth; even those two who revealed lifestyle entry motives. Ten of them had already expanded capacities; eighteen are in a process of expansion whereas five of them have already expanded, thus are involved in the second expansion. Besides the increase in the actual size of the hotel, entrepreneurs defined business growth as involving categories as presented in Table 1.

Table 1 Definition of business growth

\begin{tabular}{|l|l|}
\hline \multicolumn{1}{|c|}{ CATEGORIES OF GROWTH } & \multicolumn{1}{c|}{ CHANGES INVOLVED } \\
\hline Hotel size & $\begin{array}{l}\text { Increment in the number of letting rooms. This } \\
\text { involves expanding existing capacities if available } \\
\text { due to the space constraints or investment into a } \\
\text { new small hotel. }\end{array}$ \\
\hline Increase in quality & $\begin{array}{l}\text { Includes: construction of swimming pools, saunas, } \\
\text { small conference rooms, buying a speed boat or a } \\
\text { van. }\end{array}$ \\
\hline Employees & $\begin{array}{l}\text { This usually involves an increasing need for } \\
\text { permanent employees, even during the winter } \\
\text { times. }\end{array}$ \\
\hline Other businesses & \begin{tabular}{l} 
Investment in other businesses. \\
\hline
\end{tabular}
\end{tabular}


All these categories are desirable by entrepreneurs, although they experience administrative and financial barriers when conducting necessary actions to grow. The entrepreneurs' views on growth and economic mind-set are clearly elaborated by the following transcript extract:

'There is no entrepreneur in this world who started a businesses and does not think about expanding his job. I mean if you do not think in this way something is wrong with you, you are not a true entrepreneur.'

Interviewed entrepreneurs measure business success in terms of growth criteria and therefore put measures in place to facilitate growth opportunities. Thus, it is not surprising that the majority of the entrepreneurs expect from business higher profit and sustained growth. This further strengthens the dominance of business rather than personal or lifestyle goals.

\section{Discussion}

Presented findings are opposed to the dominant 'lifestyle' concept as presented in Western economies literature. They clearly reject the view that small business owners are driven by personal and lifestyle considerations, rather than economic business entry motives. From the foregoing it is clear that researchers have to be careful when interpreting the lifestyle concept as it is complex, socially constructed, and dependent on person, economic conditions and embedded in cultural-value system. How this relates to the study is shown through Figure 2, which encompasses Morrison's (2006) proposed 'filters'.

Figure 2 The 'filters' of entrepreneurial activity 


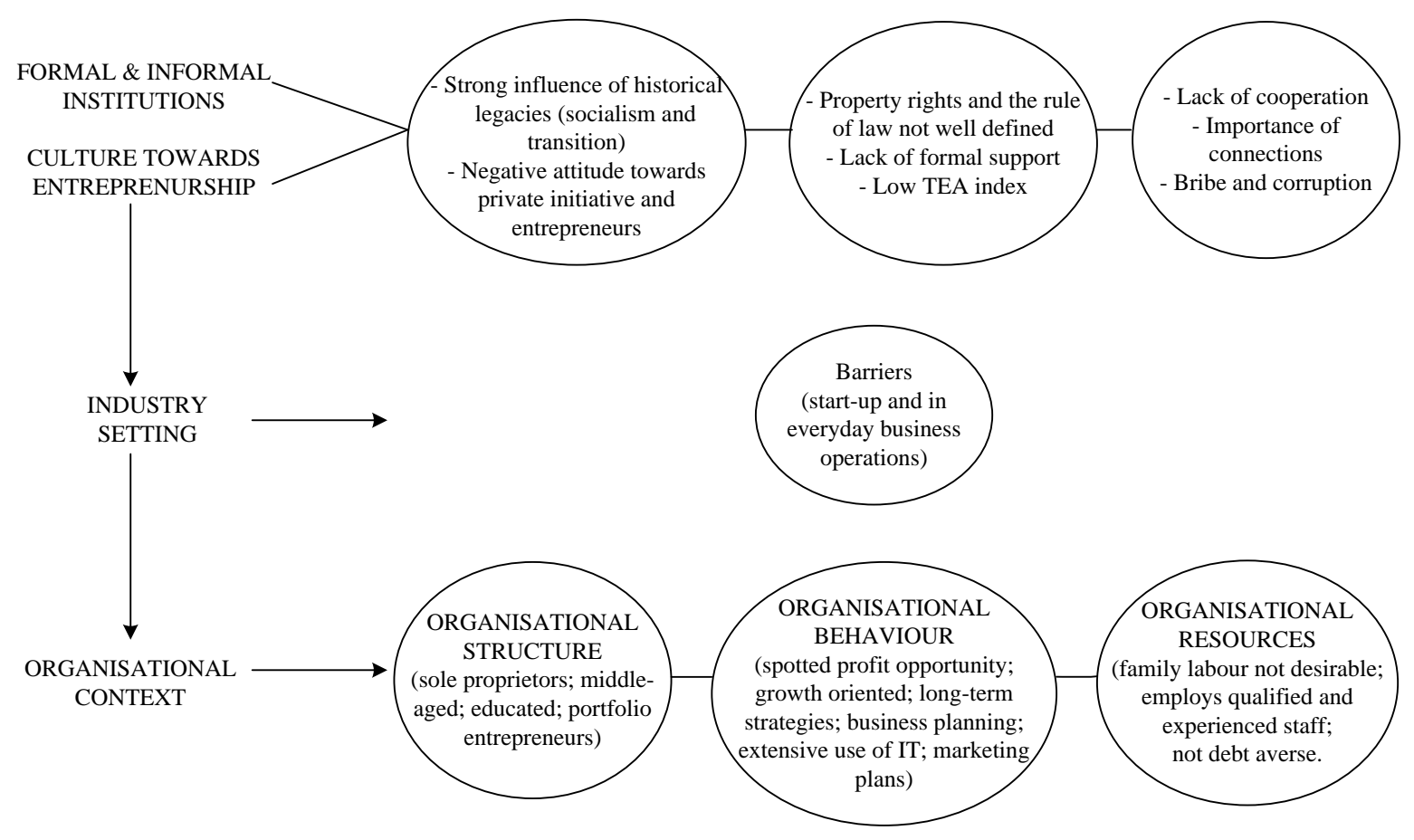

From Figure 2 it is clear that entrepreneurs simply cannot use business as a means to acquire overall 'way of life'. In terms of culture towards entrepreneurship and industry setting, it is evident that they operate in an extremely unfavourable environment for entrepreneurship, where historical legacies and the overall population's mentality make their position even harder. Formal and informal institutions are not supportive of entrepreneurship and the findings revealed that only twelve entrepreneurs did not have any start up barriers. This is in sharp contrast to the literature which examines the issue of low entry barriers inherent in the tourism and hospitality sector (for example, Dewhurst and Horobin, 1998; Morrison et al., 2001).

This is significantly reflected on the entrepreneurial behaviour and resources. In terms of the former, it is not possible to go into detail for each observed, but one of the key findings was entrepreneurial desire towards growth and perception of smallness. They all perceive the hotel size as one of the barriers in everyday business operations which: limits their scope of service; can cause problems with employees; endangers their position on the market; and also limits the negotiation power with tour operators, travel agencies and major suppliers. 
Considering resources, a remarkable finding was the entrepreneurs' rejection of family employment. They seek educated and qualified employees, and entrepreneurs do not employ family members. The majority of the entrepreneurs employ between nine and nineteen full time employees, where eight entrepreneurs had more than twenty. In terms of start-up capital, the majority combined private sources, such as money earned in other business ventures, with a bank loan (twenty-two). The share of the borrowed funds varies between $20 \%$ to $80 \%$. Eleven entrepreneurs financed overall investment with their private sources. These findings challenge the traditional view that owners of small tourism and hospitality firms, and also SMEs in general, are debt averse and perceive external borrowing as a threat to their autonomy (Stanworth and Curran, 1976).

\section{Conclusion}

The main aim of this paper was to demonstrate that the lifestyle label represents an extremely elusive concept and is determined by the 'filters' which facilitate or endanger (as in the analysed case) entrepreneurial activity. It has been outlined through a conceptualisation of entrepreneurship developed by Morrison (2006) that understanding of lifestyle entrepreneurs is best understood by reference to the cultural, industry setting and organisational context within which entrepreneurs are embedded. The importance of this paper lies in identifying this path of analysis. Although findings confirmed that the studied entrepreneurs cannot be labelled as the lifestyle entrepreneurs, the authors do not oppose the concept. They argue that the concept is derived from a Western economies discourse, therefore, it in danger of overlooking the existence of different world views and truths; different conceptions of 'lifestyle'. 
Thus, this paper argues that the contextual embeddedness of tourism entrepreneurship needs to be recognised. Researchers should be aware of the problem of partial and uncritical knowledge creation which through methodological (positivism), disciplinary (economics and business studies) and ideological (western values) bias may impede the field's development. Furthermore, in demonstrating different level of entrepreneurial behaviour compared to Croatia as a whole, this study also points to the necessary recognition of sectoral and geographical differences when researching tourism entrepreneurship. Thus, this study proposes new directions in tourism entrepreneurship research by following Ateljevic and Doorne's (2003) and Morrison's (20006) advocacy to go beyond purely economic premises and appreciate social structure and cultural background. Justification is in the belief that it will enhance the conceptualisation and better understanding of tourism entrepreneurship, encouraging researchers to extend or revise theories with new contextual variables that are grounded in the realities of the entrepreneurs.

\section{References}

Ageev, A., Gratchev, M. and Hisrich, R. (1995) Entrepreneurship in the Soviet Union and Post-Socialist Russia, Small Business Economics 7(5), pp. 365-76.

Aldrich, H. and Fiol, M. (1994) Fools Rush In? The Institutional Context of Industry Creation, Academy of Management Review 19(4), pp. 645-70.

Alexander, N. and McKenna, A. (1999) Rural Tourism in the Heart of England, International Contemporary Hospitality Management 10(5), pp. 203-07.

Allcock, J. (1986) Yugoslavia's Tourist Trade Pot of Gold or Pig in a Poke? Annals of Tourism Research 13(4), pp. 565-88.

Ateljevic, J. (2007) Small Tourism Firms and Management Practice in New Zealand: The Centre Stage Macro Region, Tourism Management 28(1), pp. 307-16. 
Ateljevic, J. (2009) Tourism Entrepreneurship and Regional Development: Example from New Zealand, International Journal of Entrepreneurial Behaviour and Research 15(3), pp. 282-308.

Ateljevic, J. and Page, S. (2009) Introduction. In J. Ateljevic and S. Page (Eds.) Tourism and Entrepreneurship: International Perspectives, pp.1-6 (London: Elsevier). Ateljevic, I. and Doorne, S. (2000) Staying with the Fence: Lifestyle Entrepreneurs in Tourism, Journal of Sustainable Tourism 8(5), pp. 378-92.

Ateljevic, I. and Doorne, S. (2003) Unpacking the Local: A Cultural Analysis of Tourism Entrepreneurship in Murter, Croatia, Tourism Geographies 5(2), pp. 123-50. Ayyagari, M., Beck, T. and Demirgue-Kunt, A. (2007) Small and Medium Enterprises Across the Globe, Small Business Economics, 29(4), pp. 415-34.

Baker, T., Gedajlovic, E. and Lubatkin, M. (2005) A Framework for Comparing Entrepreneurship Processes Across Nations, Journal of International Business Studies 36(5), pp. 492-04.

Bartlett, W. and Bateman, M. (1997) The Business Vulture in Croatia and Slovenia. In M. Bateman (Ed.) Business Cultures in Central and Eastern Europe, pp.88-127 (Oxford: Butterworth-Heinemann).

Baumol, W. (1990) Entrepreneurship: Productive, Unproductive, and Destructive, The Journal of Political Economy 98(5), 893-923.

Buhalis, D. and Murphy, H. (2009) Information Communication Technologies (ICTs), Entrepreneurship and SMTEs. In J. Ateljevic and S. Page (Eds.) Tourism and Entrepreneurship: International Perspectives, pp. 287-300 (London: Elsevier).

Buick, I., Halcro, K. and Lynch, P. (2000) Death of the Lifestyle Entrepreneur. A study of Scottish Hotel Proprietors, The Journal of Applied Hospitality Management Praxis 2(2), pp. 114-25. 
Burrell, G. and Morgan, G. (1985) Sociological Paradigms and Organisational Analysis: Elements of the Sociology of Corporate Life (London: Heinemann).

Chilosi, A. (2001) Entrepreneurship and Transition, MOCT-MOST: Economic Policy in Transitional Economies 11(4), pp. 327-57.

Church, I. and Lincoln, G. (1998) Quality management. In R. Thomas (Ed.) The Management of Small Tourism and Hospitality Firms, pp. 138-55 (London: Cassell).

Curran, J. and Blackburn, R. (1994) Small Firms and Local Economic Networks:

The Death of the Local Economy? (London: Sage).

Denzin, N. and Lincoln, Y. (2000) The Discipline and Practice of Qualitative

Research. In N. Denzin and Y. Lincoln (Eds.) Handbook of Qualitative Research, pp.1-28 (Thousands Oaks, CA: Sage).

Dewhurst, P. and Horobin, H. (1998) Small Business Owners. In R. Thomas (Ed.) The Management of Small Tourism and Hospitality Firms, pp. 19-39 (London: Cassell).

Dobbs, M. and Hamilton, R. (2007) Small Business Growth: Recent Evidence and New Directions, International Journal of Entrepreneurial Behaviour and Research 13(5), pp. 296-322.

GEM (2002) What Makes Croatia a(n) (non) Entrepreneurial Country (CEPOR: Zagreb).

GEM (2006) Sto čini Hrvatsku Poduzetničkom Zemljom? (CEPOR: Zagreb).

Getz, D. and Petersen, T. (2005) Growth and Profit Oriented Entrepreneurship Among Family Business Owners in the Tourism and Hospitality Industry, International Journal of Hospitality Management 24(2), pp. 219-42.

Glancey, K. (1998) Determinants of Growth and Profitability in Small Entrepreneurial Firms, International Journal of Entrepreneurial Behaviour and Research 4(1), pp. 1827. 
Glancey, K. and Pettigrew, M. (1997) Entrepreneurship in the Small Hotel Sector, International Journal of Contemporary Hospitality Management 9(1), pp. 21-24.

Glas, M. (1998) Eastern Europe: Slovenia. In A. Morrison (Ed.) Entrepreneurship: An International Perspective, pp. 108-24 (Oxford: Butterworth-Heinemann).

Hall, M. and Rusher, K. (2004) Risky Lifestyles? Entrepreneurial Characteristics of the New Zealand Bed and Breakfast Sector. In: R. Thomas (Ed.) Small Firms in Tourism: International Perspective, pp. $83-97$ (Oxford: Elsevier).

Hébert, R. and Link, A (1988) The Entrepreneur: Mainstream Views and Radical Critiques (New York: Praeger).

Hollinshead, K. (2004) A Primer in Ontological Craft: The Creative Capture of People and Places Through Qualitative Research. In J. Phillimore and L. Goodson (Eds.) Qualitative Research in Tourism: Ontologies, Epistemologies and Methodologies, pp. 6382 (London: Routledge).

Hornaday, J. (1990) Dropping the E-words from Small Business Research: An Alternative Typology, Journal of Small Business Management 28(4), pp. 22-33.

Ioannides, D. and Petersen, T. (2003) Tourism 'Non-Entrepreneurship' in Peripheral Destinations: A Case Study of Small and Medium Tourism Enterprises on Bornholm, Denmark, Tourism Geographies 5(4), pp. 408-35.

Ireland, D., Tihanyi, L., and Webb, J. (2008) A Tale of Two Politico-Economic Systems: Implications for Entrepreneurship in Central and Eastern Europe, Entrepreneurship Theory and Practice 32(1), pp. 107-130.

Kobašić, A. (1987) Turizam u Jugoslaviji: Razvoj, Stanje i Perspektive. (Zagreb: Informator).

Kolodko, G. (2000) Transition to a Market and Entrepreneurship: The Systemic Factors and Policy Options, Communist and Post-Communist Studies 33(2), pp. 271-93. 
Komppula, R. (2004) Success and Growth in Rural Tourism Micro-Businesses in Finland: Financial or Lifestyle Objectives? In: R. Thomas (Ed.) Small Firms in Tourism: International Perspective, pp. 115-38 (Oxford: Elsevier).

Kovac, B. (1990) Političko-Ekonomska Uloga Poduzetništva. In D. Njavro and V. Franičević (Eds.) Poduzetništvo: Teorija, Politika, Praksa, pp. 69-93 (Zagreb: Privredni Vjesnik).

Lashley, C., and Rowson, B. (2010) Lifestyle Businesses: Insights into Blackpool's Hotel Sector, International Journal of Hospitality Management 29(3), pp.511-19.

Li, L. (2008) A Review of Entrepreneurship Research Published in the Hospitality and Tourism Management Journals, Tourism Management 29(5), pp. 1013-22.

Lockyer, C. and Morrison, A. (1999) Scottish Tourism Market: Structure, Characteristics and Performance, Scottish Tourism Research Unit/Fraser of Allander Institute, University of Strathclyde, Glasgow.

Low, M. and Abrahamson, E. (1997) Movements, Bandwagons, and Clones: Industry Evolution and the Entrepreneurial Process, Journal of Business Venturing 12(6), pp. 435-58.

Lynch, P. (1998) Female Entrepreneurs in the Host Family Sector: Key Motivations and Socio-Economic Variables, International Journal of Hospitality Management 17(3), pp. $319-42$.

Manolova, T., Eunni, R. and Gyoshev, B. (2008) Institutional Environments for Entrepreneurship: Evidence from Emerging Economies in Eastern Europe, Entrepreneurship Theory and Practice 32(1), pp. 203-18.

Morrison, A. M., Pearce, P., Moscardo, G., Nadkarni, N. and O’Leary, J. (1996) Specialist Accommodation: Definition, Markets Served, and Roles in Tourism Development, Journal of Travel Research 35(1), pp.18-25. 
Morrison, A. (2006) A Contextualisation of Entrepreneurship, International Journal of Entrepreneurial Behaviour and Research 12(4), pp.192-209.

Morrison, A., Baum, T. and Andrew, R. (2001) The Lifestyle Economics of Small Tourism Businesses, Journal of Travel and Tourism Research 1(1-2), pp. 16-25. Morrison, A. and Teixeira, R. (2004) Small Business Performance: A Tourism Sector Focus, Journal of Small Business and Enterprise Development 11(2), pp. 166-73.

Morrison, A., Carlsen, J. and Weber, P. (2009) Lifestyle Oriented Small Tourism (LOST) Firms and Tourism Destination Development. CAUTHE Conference Proceedings. Australia.

Mottiar, Z. (2007) Lifestyle Entrepreneurs and Spheres of Inter-Firm Relations, Entrepreneurship and Innovation 8(1), pp. 67-74.

North, D. (1990) Institutions, Institutional Change, and Economic Performance (New York: Norton).

Ogbor, J. (2000) Mythicising and Reification in Entrepreneurial Discourse: IdeologyCritique of Entrepreneurial Studies, Journal of Management Studies 37(5), pp. 605-35.

Page, S., Forer, P. and Lawton, G. (1999) Small Business Development and Tourism: Terra Incognita? Tourism Management 20(4), pp. 435-59.

Patton, M. (2002) Qualitative Research and Evaluation Methods (Thousands Oaks: Sage).

Peacock, M. (1993) A Question of Size, International Journal of Contemporary Hospitality Management 5(4), pp. 29-32.

Pirjevec, B. And Kesar, O. (2002) Pocela Turizma (Zagreb: Mikrorad i Ekonomski Fakultet).

Reynolds, P., Bygrave, W. and Autio, E. (2003) GEM 2003 Executive Report (Babson Park, MA: Babson College). 
Ritchie, J. and Spencer L. (1994) Qualitative Data Analysis for Applied Policy Research. In A. Bryman and R. Burges (Eds.) Analysing Qualitative Data, pp. 173-94 (London: Routledge).

Scase, R. (2003) Employment Relations in Small Firms. In P. Edwards (Ed.) Industrial Relations: Theory and Practice, pp. 470-89 (Oxford: Blackwell).

Scase, R. and Goffee, R. (1989) The Real World of the Small Business Owner (London: Routledge).

Schumpeter, J. A. (1934) The Theory of Economic Development (Cambridge: Harvard University Press).

Shaw, G. and Williams, A. (1987) Firm Formation and Operating Characteristics in the Cornish Tourist Industry-The Case of Looe, Tourism Management 8(4), pp. 344-48.

Shaw, G. and Williams, A. (1998) Entrepreneurship, Small Business, Culture and Tourism Development. In D. Ioannides and K. Debbage (Eds.) The Economic Geography of the Tourist Industry: A Supply-Side Analysis, pp. 235-55 (London: Routledge).

Shaw, G. and Williams, A. (2004) From Lifestyle Consumption to Lifestyle Production: Changing Patterns of Tourism Entrepreneurship. In: R. Thomas (Ed.) Small Firms in Tourism: International Perspective, pp. 99-113 (Oxford: Elsevier).

Shepherd, J. and Wiklund, D. (2005) Entrepreneurial Orientation and Small Business Performance: A Configurational Approach, Journal of Business Venturing 20(1), pp. 71-91.

Skokic, V. (2010) Tourism Entrepreneurship in Transition Economies: Unpacking the Socio-Economic Contexts. Unpublished PhD Thesis. University of Strathclyde, Glasgow.

Stanworth, M. and Curran, J. (1976) Growth and the Small Firm: An Alternative View, 
Journal of Management Studies 13(2), pp. 95-110.

Stone, M. and Brush, C. (1996) Planning in Ambiguous Contexts: The Dilemma of Meeting Needs for Commitment and Demands for Legitimacy, Strategic Management Journal 17(8), pp. 633-52.

Strauss, A. and Corbin, J. (1998) Basics of Qualitative Research: Techniques and Procedures for Developing Grounded Theory. (Thousand Oaks, CA: Sage).

Szivas, E. (2001) Entrance into Tourism Entrepreneurship: A UK Case Study, Tourism and Hospitality Research 3(2), pp. 163-72.

Taylor, E. (2008) HACCP for the Hospitality Industry: History in the Making, International Journal of Contemporary Hospitality Management 20(5), pp. 480-93.

Thomas, R. (2004) International Perspectives on Small Firms in Tourism: A Synthesis. In R. Thomas (Ed.) Small Firms in Tourism: International Perspective, pp.1-12 (Oxford: Elsevier).

Timmons, J. (1994) New Venture Creation (Boston, MA: Irwin).

Vukonic,B. (2005) Povijest Hrvatskog Turizma (Zagreb: Prometej).

Williams, A., Shaw, G. and Greenwood, J. (1989) From tourist to tourism Entrepreneur, from Consumption to Production: Evidence from Cornwall, England, Environment and Planning A21(12), pp. 1639-53. 